\title{
Authority and Function of Pecalang Organization in Maintaining Public Safety and Conformity (Research Study in Dangin Puri Kaja Village, Denpasar)
}

\author{
$1^{\text {st }}$ M M Sofyan \\ Public Administration Department \\ Universitas Muhammadiyah Bandung \\ Bandung, Indonesia \\ metimedia@gmail.com
}

\author{
$2^{\text {nd }}$ E I Supriyadi \\ Public Administration Department \\ Universitas Muhammadiyah Bandung \\ Bandung, Indonesia \\ endangirawan.ei@gmail.com
}

\begin{abstract}
A pecalang (Balinese religious leader) has a lot of responsibilities. Not only maintaining village safety, especially related with religion and ceremonial matters, but also maintaining the safety of complex public activities. Therefore, a pecalang should not only having abilities related with tradition and religious issues, but also having the ability to solve immigrant residents in Dangin Puri Kaja Village of Denpasar. Based on such understanding, it is important to understand the characteristics of authority and function of Pecalang organization in Dangin Puri Kaja Village, and what are the difficulties faced in performing their authoritative duties. Qualitative method is used in this research, using interview research instrument. From the research, it can be understood that the authority of pecalang of Dangin Puri Kaja Village of Denpasar includes public safety and conformity of Dauh Puri Kaja Village monitoring, public safety duties in Dangin Puri Kaja Village in terms of religious and tradition, and appointed and dismissed by Dangin Puri Kaja Village. Several difficulties faced by Pecalang of Dangin Puri Kaja Village including the unavailability of dedicated office or post until now, therefore hindering their public official duties.
\end{abstract}

\section{Keywords-Function, Pecalang, Denpasar, Dangin Puri}

\section{INTRODUCTION}

Dangin Puri Kaja Village is a community that has a customary law style of unity of tradition and etiquette of the Hindu community, passed down from generation to generation in a boundary of Kahyangan Tiga, regional autonomy, and its own assets. With this understanding, Dangin Puri Kaja Village is a traditional institution that has a social religious character and has an autonomous government based on its original rights. In other words, in terms of governance, Desa Dangin Puri Kaja can establish its own rules or also referred to as awig-awig rules.
Village awig-awig was compiled based on the Tri Hita Karana philosophy, which is a philosophy that emphasizes on the harmonious relationship between humans and God Almighty, humans with fellow humans, and humans with nature. Based on Bali Province Regional Regulation No. 4/2019 concerning Dangin Puri Kaja Village, it has been determined that pecalang should be the responsible party in maintaining order and security of the Dangin Puri Kaja village area. They also should perform security tasks in the territory of the village of Dangin Puri Kaja in relations with religious and customs duties. In order to become a pecalang, every pecalang should be appointed and dismissed by Dangin Village Puri Kaja based on village paruman. Based on the ability to elect their own pecalang through the village paruman, the people of Dangin Puri Kaja village has a solid foundation to play a role in the implementation of regional autonomy, in order to realize public safety and order, and to achieve prosperity and society welfare, in accordance with their potential.

Based on such understanding, it can be perceived that pecalang is a security means belonging to the Puri Kaja Dangin Village of Denpasar. With the increasing complexity of society development, so does the tasks of a pecalang. Their task is not only to maintain the security of the village in terms of traditional ceremonies and religion, but also to maintain safety in community activities.

Such social tasks including handling immigrants-related issues in the village of Dangin Puri Kaja Denpasar. Settling newcomers in Dangin Village Puri Kaja will be handled by the Village Head, Kelian Dinas, Benda Adat and local pecalang. In addition to the problem of handling public order in the area of Dangin Puri Kaja Village, as an organization, pecalang should have a clear structure and activities plan, and supported with suitable 
facilities and infrastructure in carrying out their duties so that they can function optimally. Based on this background, this research was conducted to find out the authority and function of the pecalang organization in the Dangin Puri Kaja Village of Denpasar.

\section{Problem Formulation}

1. What are the characteristics of the authority and function of the Pecalang Organization in the Dangin Puri Kaja Village Denpasar?

2. What constraints are faced in exercising the authority and functions of the Pecalang organization in the Dangin Puri Kaja Village Denpasar?

\section{CONCEPT}

\section{A. Authority and Function}

Authority is the right to take action, ask someone else to take an action, or not to act at all. The point of view for an authority is as a receiver of orders, not as a giver of orders. Such view begins with the observation that not all of the recipients of such orders would obey. They have the choice to follow orders or not.

Authority according to Hasibuan (2006-57) is "a legitimate and legal means that belongs to someone for ordering others to perform something or not. Authority is a legitimate legal basis in order to perform an action."

\section{B. Organization}

Organization is a tool or a cooperative body for the sake of achieving mutual goal with a certain pattern. An organization has both physical and non physical wealth. Therefore, a conflict in an organization often occurs when there is a misalignment of objectives and differences in interpretation of a fact that emerges within the organization.

Based on the above understanding, organization in this research is interpreted as a means of cooperating to achieve a common goal as practiced by a pecalang in each local traditional village. They have a pecalang ogrganization which is responsible in maintaining security and order in the traditional village during religious ceremonies or related activities in traditional village.

\section{Pecalang}

Pecalang comes from several words: based on the Old Javanese Dictionary, it comes from the word "Cala" which means to move. It is derived from the word "Pe" which means "Pascad" which means intelligent and the word celang which has the meaning of cautious/ sharp, namely: cautious eye, cautious mind, cautious ear as well as cautious hand and foot. Therefore, Pecalang means "someone who is in charge of overseeing / maintaining security in the area of Dangin Puri Kaja Village.

In article 1 paragraph (22) of Regional Regulation of Bali Province no. 4 of 2019, it is explained that Pecalang is a traditional security unit (task force) of the Balinese people who has the authority to maintain security and order in Dangin Puri Kaja Banjar area and/ or in the area of Dangin Village Puri Kaja Denpasar (Perda No. 4 of 2019).

\section{THEORETICAL BASIS}

The theoretical basis used by researchers to dissect a problem related to the authority and function of pecalang in the village of Dangin Puri Kaja Denpasar .

\section{A. Theory of Authority}

In every study, a theory is needed that is used as a basis. For that reason, the researchers use the theory of authority described in the Big Indonesian Dictionary which means the right and power to do something.

Rational-legal authority is a form of authority that develops in the life of modern society. This kind of authority is built when there is legitimacy that is enjoyed by the authorities. This authority is owned to regulate human relations in a power relation.

"Authority is a formal ability to achieve certain goals and be accepted by society. Whereas power is the ability that a person has to influence others without being related to the formal acceptance of a social order. In other words, power is the ability to influence or determine the attitude of others over the desires of the owner of power. " According to Weber (1999: 155).

Max Weber (1999-157) divides authority into the following three types:

1. Organizations, especially political ones.

Rational-legal authority does not base the strength of its legitimacy on habits but on all written rules. If defined, rational means reasonable, and legal means part of the law.

Therefore, legal rational means something that makes sense and is written as a certain law or regulation. The agreed matter can be broad, such as a constitution detailing the rights of all members of a society, or narrow in nature, such as the interaction of two individuals. Because bureaucracy always based on written rules, then the authority of the rational-legal and often also referred to as bureaucratic authority.

Rational-legal authority comes from a position someone occupies, not from someone who holds a position. In a democracy, for example, the authority of a president comes from his position detailed in the constitution of a written agreement, not from the personal habits of individuals. Under legal authority, every individual no matter how high their position must be subject to written organizational rules. In the case of traditional authority, the words of the authorities are considered as law, but in rational-legal authority, the authorities are subject to the law.

2. Traditional authority is a type of authority that develops in traditional life. The legitimacy of such authority is based on traditions that are considered sacred and divided into two types of authority, namely patriarchalism and patrimonialism.

Patriarchism is an authority with seniority as the basis of its power. Traditionally, those who are older or senior are considered to have a higher position.

While patrimonialism is an authority where a leader must cooperate with fellow relatives or with the closest people who have loyalty. Traditional ties play a major role in the authority's patriarchism and patrimonialism. Figures of authority must come from those who understand the depth of such sacred tradition.

The appointment of authority must be based on personal relationships and on the personal loyalty of the candidate to the previous leader. This type of authority has 
a typical characteristic in which the system of norms is viewed as sacred and cannot be contested. Violation of these norms will cause disasters whether they are occult or religious in nature.

3. Charismatic authority, the authority that a person has when the owner of that authority has extraordinary qualities. That is because being a charismatic figure is an extraordinary quality of authority. Society does not even question whether the quality is visible or just a conjecture. Therefore charismatic authority can dominate an individual with external and internal predominance, so that because of belief in these extraordinary qualities, an individual becomes subject and obedient to the authority.

\section{RESEARCH METHODS}

This study used qualitative research methods. Qualitative research according to Irawan (2001: 13), "Qualitative research is an artistic method, because the research process is more art-centric or less patterned. So the data found depends on the conditions of implementation in the field. "

Data analysis is more inductive or qualitative, and qualitative research results emphasize on meaning rather than generalization. Qualitative research in general has the following characteristics:

- Having a natural background in which researchers themselves become the core instrument, researchers spend more time in the study area to observe and understand the problem in depth. Assisted with research aids in the form of a recorder or tape recorder and camera from preparation until the end of the communication process carried out by the interpreter of the Dangin Puri Kaja Village, Denpasar.

- Having a descriptive nature, in this case illustrates verbal data and images rather than numerical data.

The written report often cites some data in order to show the importance of the findings:

- Emphasize on the process rather than the product

- Tend to analysis data using inductive approach, or departing from the specific things that could be gathered; and

- Attach great importance to the role of meaning or views, in which an action or symptoms can have several meanings (Mulyana 2001: 145).

The type of data used in this study is qualitative data, that is intangible data but is realized in the form of a description or sentence. Qualitative data related to the categorization of characteristics in the form of questions or in the form of words.

This data can be disclosed in ordinal or ranking form. While "data sources are primary and secondary data." (Riduwan 2004: 106)

\section{RESULTS OF PECALANG AUTHORITY CHARACTERISTICS}

The researchers discover the existence and differences of such three types of authority. There is a relationship between an action with a legal basis. Charismatic authority is an authority based on the disposition and positive aura of oneself. This traditional authority has the power and authority that has been handed down through generations and admitted by the people. The owner of such authority does not only possess a special ability.

The duties and authority of Pecalang in Dangin Puri Kaja Village brought a big influence on the local community so that the process of activities within the community can run smoothly in the religious field and in the social work system. This is because the activities carried out by traditional institutions and offices are always inseparable with the existence of theories that will be applied in the community. Therefore, the existence and authority of pecalang in general should have the right and the authority that has been given by local communities to support any activities related to the community so they can be maintained and create a sense of communal harmony.

Constraints faced in carrying out the duties and functions of Pecalang in Dangin Puri Kaja Village and the efforts made are the constraints faced in the exercise of authority and function of pecalang organizations in Abianbase village.

According to the Chairman Pecalang of Dangin Puri Kaja village, Gede Cahyadi, regular obstacles that are faced by Pecalang in implementing authority is when they perform official banjar functions such as securing migrants control, as pecalang is involved with data collection and inspection of migrants who do not have a certificate letter/ identity card of migrant resident. Considering that pecalang are definitely on duty on the road in traditional activities/ odalan or Ngaben ceremonies because the Dangin Puri Kaja area is near the city, so the traffic lane is very congested. Efforts to overcome these constraints including coordinating with the police force and sharing security duties with them. For example, when there is an event or ceremony that utilizes public roads, traffic management would be necessary. Equipment and tools that have been prepared in the form of flashlights, traffic signs, handy-talkies or communication tools, and whistles to perform such tasks.

\section{CONCLUSION}

Based on the results of research and discussion of the authority and function of pecalang organization in Dangin Puri Kaja Village, Denpasar District, the following conclusions can be given:

- The main responsibility of a pecalang is to secure activities related to religion, customs and culture in the local pakraman village environment. For pecalang elections in the village of Dangin Puri Kaja Denpasar, a charismatic figure is preferred, in which a preferred pecalang should really have the ability to coordinate and organize the implementation of the activities of customs and religion, authoritative, resolute, courageous, and responsible. Therefore pecalang election should be carried out in a village paruman.

- In carrying out the authority and functions, pecalang of Dangin Puri Kaja village of Denpasar experienced several problems, such as unavailability of dedicated space for pecalang activities, unavailability of a place to perform beat monitoring, the need to improve existing infrastructure and its maintenance budget, 
and a need of storage facility to store pecalang equipment.

\section{SUGGESTIONS}

Based on the conclusions above, the following suggestions can be submitted:

- Pecalang as figures of authority of Dangin Puri Kaja Village of Denpasar shall remain enforcing written regulations as legal guidelines for Dangin Puri Kaja village of Denpasar to maintain stability of the village in order to remain steady. If such customs are violated, the regularity of Dangin Puri Kaja village of Denpasar will succumb to the changes of time.

- A deep consideration needs to be involved in term of electing pecalang through paruman, therefore the elected pecalang should be individuals with high responsibility, able to manage and maintin activities in the village, especially those related to traditional, religious, and cultural ceremonies.

- Dangin Puri Kaja Village of Denpasar is expected to build a building/office/post for pecalang to make it easier for them to do their activities, or for them to keep their equipment because until now there is no dedicated place allocated for pecalang in the traditional village of Dangin Puri Kaja of Denpasar.

- Provide a budget allocated for the maintenance of facilities and infrastructures owned by Pecalang in carrying out their responsibilities.

\section{REFERENCES}

[1] Agustino L 2006 Politik dan Kebijakan Publik (Bandung : AIPI Bandung).

[2] Lukmam A 1991 Kamus Besar Bahasa Indonesia (Jakarta : Balai Pustaka).

[3] Ardana and Gede G I 1982 Sejarah Perkembangan Hinduisme di Bali Denpasar

[4] Arikunto and Sukarsimin 1998 Prosedur Penelitian Suatu Pendekatan Praktek (Jakarta : Rhineka Cipta).

[5] Cholid, Nurboko et al. 2001 Metode Penelitian Kualitatif (Jakarta : Remaja Rosdakarya).

[6] Effendi and Sofyan 1983.Metoda Penelitian Survey.Jakarta : LP3S,Matahari Bhakti.

[7] Gorda and Ngurah G I 1997 MetodologiPenelitian (Denpasar : Widya Kriya Gunatama)

[8] Gulo W 2004 Metodologi Penelitian (Jakarta : Gramedia).

[9] Iqbal and Hasan 2002 Metode Penelitian dan Aplikasinya (Jakarta : Ghalia Indonesia).

[10] Irawan and Prasetya 1998 Logika dan Prosedur Penelitian (Jakarta : STIA-LAN Press Kliping Bali Post).

[11] Mukadjir 1990 Metode Penelitian (Bandung : IKIP).

[12] Muslimin 2002 Metode Penelitian Dibidang Sosial.

[13] Nasution 1996 Metode Research (Jakarta : BumiAksara).

[14] Saifudin and Azwar 1997 MetodePenelitian (Yogyakarta : Pustaka Belajar)

[15] Sedarmayanti 2002 MetodePenelitian (Jakarta : BumiRaksa)

[16] Simanjuntak 1985 PatologiSosial (Bandung : Tarsito).

[17] Soetomo 1985 Dasar-Dasar Interaksi (Surabaya : Usaha Persada).

[18] Sunggono and Bambang 2006 Metodologi Penelitian Hukum Jakarta : Raja Grafindo Persada.

[19] Wiana and Ketut Drs 1998 Pecalang Benteng Terakhir Bali Surabaya : Paramita.

[20] Sirtha 2006 Ajeg Bali Pecalang dan Pendidikan Budi Pekerti Denpasar : SIC.

[21] Windia and Wayan 1995 Menjawab Masalah Hukum Bali : Penerbit Bp.Denpasar

[22] Winarno 1979 Reseach Pengantar Metodologi Bandung : IKIP.
[23] Peraturan Daerah Provinsi Bali Nomor 4 pasal 47 tahun 2019 tentang Desa Adat Bali

[24] Galinsky, A. D., Magee, J. C., Gruenfeld, D. H, Whitson, J. A., \& Liljenquist, K. A. (2008). Power reduces the press of the situation: Implications for creativity, conformity, and dissonance. Journal of Personality and Social Psychology, 95(6), 1450-1466. https://doi.org/10.1037/a0012633

[25] John W. Meyer and Brian Rowan. (2020). Institutionalized Organizations: Formal Structure as Myth and Ceremony. American Journal of Sociology 1977 83:2, 340-363

[26] Forstén, J. Future direction for measurement, testing and conformity assessment. Accred Qual Assur 8, 498-504 (2003). https://doi.org/10.1007/s00769-003-0676-y

[27] Bond, R., \& Smith, P. B. (1996). Culture and conformity: A meta-analysis of studies using Asch's (1952b, 1956) line judgment task. Psychological Bulletin, 119(1), 111137. https://doi.org/10.1037/0033-2909.119.1.111

[28] Blowfield, M. and Frynas, J., G. (2005). Setting New Agendas: Critical Perspectives on Corporate Social Responsibility in the Development of the Developing World. International Affairs, 81 (3), pp. 499-513.

[29] Carriga, E. and Melé, P. (2004). Corporate Social Responsibility Theories: Mapping the Territory. Journal of Business Ethics, 53, pp. 51-71

[30] Darnall, N. (2003). Why Firms Certify to ISO 14001: An Institutional and Resource Based View. Academy of Management Best Conference Paper, 2003

[31] Denscombe, M. (2003). The Good Research Guide. Maidenhead: Open University Press.

[32] Doane, D. (2005). Beyond Corporate Social Responsibility: Minnows, Mammoths and Markets. Futures, 37 (2/3), pp. 215-229.

[33] Goodstein, J. (1994). Institutional Pressures and Strategic Responsiveness: Employer Involvement in Work Family Issues. Academy of Management Journal, 37, pp. 350-382.

[34] Hamann R. and Acutt, N (2003). How Should Civil Society (and the government) Respond to Corporate Social Responsibility'? A Critique of Business Motivations and the Potential for Partnerships. Development Southern Africa, 20 (2), pp. 255-270. 